\title{
Erratum to: Non-crop plants used as hosts by Drosophila suzukii in Europe
}

\author{
Marc Kenis $^{1} \cdot$ Lorenzo Tonina $^{2} \cdot$ René Eschen $^{1} \cdot$ Bart van der Sluis $^{3}$. \\ Manuel Sancassani ${ }^{2} \cdot$ Nicola Mori $^{2} \cdot$ Tim Haye $^{1} \cdot$ Herman Helsen $^{3}$
}

Published online: 11 March 2017

(c) Springer-Verlag Berlin Heidelberg 2017

\section{Erratum to: J Pest Sci (2016) 89:735-748 DOI 10.1007/s10340-016-0755-6}

The article was originally published Online First without open access. After publication in Volume 89, Issue 3, pp. 735-748 the author decided to opt for Open Choice and to make the article an open access publication. Therefore, the copyright of the article has been changed to
(C) The Author(s) [2017] and the article is forthwith distributed under the terms of the Creative Commons Attribution 4.0 International License (http://creativecommons. org/licenses/by/4.0/), which permits use, duplication, adaptation, distribution and reproduction in any medium or format, as long as you give appropriate credit to the original author(s) and the source, provide a link to the Creative Commons license, and indicate if changes were made.

The online version of the original article can be found under doi:10.1007/s10340-016-0755-6.

Marc Kenis

m.kenis@cabi.org

1 CABI, 2800 Delémont, Switzerland

2 Department of Agronomy, Food, Natural Resources, Animals and Environment (DAFNAE), University of Padova, 35020 Legnaro, PD, Italy

3 Applied Plant Research, Wageningen University \& Research, 6670 AE Zetten, The Netherlands 